\title{
Biological Maturity Status and Motor Performance in Fourteen-Year-old Basketball Players
}

\author{
Estado de Madurez Biológica y Desempeño Motriz en \\ Jugadores de Baloncesto de Catorce Años de Edad
}

Sasa Jakovljevic*; Marija Macura*; Mandic Radivoj*; Nenad Jankovic"; Zoran Pajic* \& Frane Erculj**

JAKOVLJEVIC, S.; MACURA, M.; RADIVOJ, M.; JANKOVIC, N.; PAJIC, Z. \& ERCULJ, F. Biological maturity status and motor performance in fourteen-year-old basketball players. Int. J. Morphol., 34(2):637-643, 2016.

SUMMARY: The aims of this study were to detect biological maturity and certain athletic skills in boys aged 14 participating in competitive basketball, and to compare certain athletic skills of participants according to their biological maturity status. The participants were most talented Serbian basketball players $(n=49)$ who were divided into three groups according to their maturity status: early $(n=$ 14), average $(n=24)$ and late maturing $(n=11)$. Biological maturity status of participants was assessed by technique developed by Mirwald et al. (2002). Nine tests of basic athletic skills: vertical jump, medicine ball throwing, run at 20, 30 and $50 \mathrm{~m}$, agility t-test, zigzag agility drill, agility run $4 \times 15 \mathrm{~m}$, the line drill, as well as four basketball skills field tests (speed spot shooting, passing, control dribble and defensive movement) were applied. The results of this study showed that the three groups of subjects differed in applied variables ( $\mathrm{p}<0.05$ ). Average maturers achieved the best results in almost all variables, while late maturers achieved the worst results. Early maturers achieved the best results only in one variable - medicine ball throwing. Only harmonized chronological and biological age, i.e. chronological and biological growth and development, enable the best demonstration of motor abilities based on morphological characteristics.

KEY WORDS: Chronological age; Biological age; Motor abilities; Basketball skills.

\section{INTRODUCTIO N}

Sports activities are a very important means in the process of overall development of young people. Basketba11 is a very popular sport which is part of the entire process of physical education in schools. A large number of children also practice basketball in clubs, most of them of pre-puberty and puberty ages. During both pre-puberty and puberty periods there is a high variability in the degree of development of organ systems and physical/psychological characteristics of the young. Differences among child athletes of various chronological ages are in most cases clearly noticeable in most anthropometric measurements (especially body height), as well as in their motor and functional abilities (Beunen et al., 1992; Malina et al., 2000, 2004a). It is similar in young basketball players (Buchanan \& Vardaxis, 2003). When body height is considered, a number of studies dealing with height of children who do not participate in sports, in relation to children who train sports, show that regular training does not influence body height (Malina, 1994;
Malina et al., 2004b). Growing of both athletes and nonathletes occurs according to the same regularities without deviations in dynamics, tempo, and age when peak high velocity occurs (PHV). PHV is usually considered as one of the indicators of biological maturity (Malina). Training has no significant influence on growth and maturing, but children who practice sports usually have better motor and functional abilities (Beunen et al.). Apart from growth, other factors which can influence biological age such as genetic factors, being underweight considering the intensity and degree of training, diet etc (Macura et al., 2010), have to be taken into consideration and analyzed.

In certain researches (Buchanan \& Vardaxis, 2003; Coehlo E Silva et al., 2008) children of similar chronological age, for example, 14 and 15-year- olds or 11 to 13 -yearolds, are placed into the same subject groups, since they do not differ considerably in certain motor abilities. Sports 
practice shows that in pre-puberty and puberty ages there are differences between chronological and biological ages of boy athletes (Beunen et al.; Malina et al., 2000, 2004a; Iuliano-Burns et al., 2001). Differences in their biological age can also occur within groups of boy athletes of the same chronological age (Sinobad, 2005). For example, biological age of two boys of the same chronological age can differ. In that case, differences in certain morphological, functional and motor characteristics can occur depending on their biological maturity, mostly ones connected with muscle mass (Sherar et al., 2007). Boy athletes (as well as basketball players) with higher biological age often achieve better competition results (playing performance) when compared to the ones with lower biological maturity (Torres-Unda $e t$ al., 2013). That is why during the process of selection in sports practice average and early maturing boys are selected more often than the late maturing ones (Malina et al., 2000). These boys were usually born during the first part of the year, from January to June (Sherar et al.). However, there are very few researches dealing with the question of differences between child athletes of the same chronological age, except the researches regarding the influence of relative age effect (Delorme \& Raspaud, 2009).

Based on basketball practice experience, it is assumed that early maturing boys would achieve better results in tests of motor abilities and basketball skills, when compared with average and late maturing players. Based on this assumption, the aims of this study were: a) to detect biological maturity and certain athletic skills in boys aged 14 participating in competitive basketball, b) to compare certain athletic skills of participants according to their biological maturity status.

\section{MATERIAL AND METHOD}

Participants. The best 14-year-old male basketball players ( $n=49$; age: 14.09 \pm 0.25$)$ from all regions of Serbia were selected from Serbian Basketball Federation by experts according to their basketball potential. They were divided into three groups according to their biological maturity status: early $(n=14$; age: $14.13 \pm 0.23)$, average $(n=24$; age: $14.14 \pm 0.22)$ and late maturity $(\mathrm{n}=11$; age: $13.96 \pm 0.30)$ basketball players. The players took part both in regional and national competitions. All players were at the end of the regular season. Parents or guardians of all participants gave formal consent before the research. All tests were conducted under the supervision of the Ethics Committee of Belgrade University Faculty of Sport and Physical Education.

Biological maturity status. Biological maturity status of participants was assessed by technique developed by
Mirwald et al. (2002). They created specific equations to estimate the maturity offset for boys:

Maturity offset $=-9.236+0.0002708$ (leg length $\times$ sitting height $)-0.001663$ (age $\times$ leg length $)+0.007216$ (age $\times$ sitting height $)+0.02292$ (weight: height)

Groups of participants (early, average and late maturers) were formed according to Wickel and Eisenman's study (Wickel \& Eisenman, 2007). Since Maturity offset represents the number of years passed since peak height velocity (PHV) occurred, it was used to estimate the age when PHV (EAPHV) occurred by subtracting maturity offset from athletes' ages. According to this, average maturing players were players with an EAPHV within \pm 0.5 years of average EAPHV; early maturers were players with an EAPHV below \pm 0.5 years of average EAPHV; and late maturers were players with an EAPHV above \pm 0.5 years of average EAPHV.

Variables. Anthropometric measurements included body height, sitting height and body mass; leg length was calculated by subtracting sitting height from body height. Body height and sitting height were measured with a stadiometer (Seca $220, \mathrm{UK})$, to the nearest $0.1 \mathrm{~cm}$. Body mass was measured using portable scales (Tanita BF683W, GER) to the nearest $0.1 \mathrm{~kg}$. Body Mass Index (BMI) was calculated according to the following formula: body mass/square body height.

Four well-known agility tests were applied: agility Ttest, zigzag agility drill, the line drill and agility run $4 \times 15 \mathrm{~m}$. Time in seconds and hundreds of seconds was determined using an electronic timing system (Micro Gate, IT).

Agility T-Test. T-test is widely used by sport researchers as well as coaches and has been established as a valid and reliable method to measure linear to lateral agility (Pauole et al., 2000; Seminick, 1990a).

Zigzag Agility Drill. This is an agility test performed at a basketball court (Fig. 1). The participants start the test at cone 1 with their one hand in contact with the cone and their feet behind the baseline. After that they sprint to cones 2, 3 and 4, then back to cone 1 (participants have to touch each cone; all cones are $30 \mathrm{~cm}$ high). For each participant, the better time of two trials is recorded (Bloomfield et al., 1994).

The Line Drill. A player starts from the base line and starts to sprint on command as fast as possible up and down the basketball court: full court, further free throw line, central line, and closer free throw line, respectively. This is a test with high reliability: correlation coefficients between test and retest amount to 0.93 (Seminick, 1990b). 


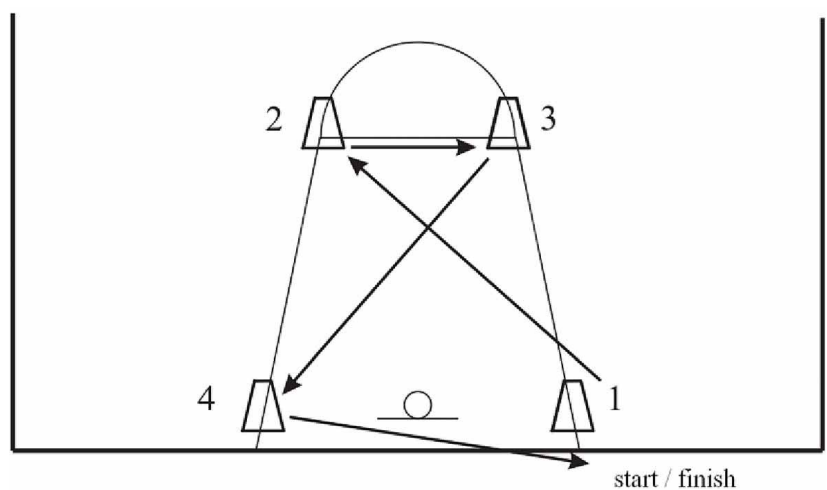

Fig. 1. Zigzag Agility Drill.

Agility Run 4x15 m. A 15-meter track borders with two lines of basketball court. All participants must complete 4 lengths of $15 \mathrm{~m}$. They are required to sprint straight to the $15 \mathrm{~m}$ line, pass that line with both their feet, and after that sprint back to the start line, pass the start line and repeat this process once more (Kurelic et al., 1975).

Three speed tests (20, 30 and $50 \mathrm{~m}$ run) were applied. Time in seconds and hundreds of seconds was also measured using an electronic timing system (Micro Gate, IT). Run 20 m. A 20-meter track at the stadium, with photocells positioned on 20 from the starting line at a height of $1 \mathrm{~m}$ was used in this part of the research. The participants started from a standing position, with one foot placed forward 70 $\mathrm{cm}$ before the first photocell and were required to sprint 20 m. This test showed high level of reliability: correlation coefficients between test and retest amounted 0.91 (Moir et al., 2004). Exactly the same procedure was followed for 30$\mathrm{m}$ and 50-m sprint tests, with corresponding distances.

Vertical jump-reach test was conducted according to the research of (Bloomfield et al.). The player dips the fingers of his right hand in gym chalk, stands by the wall and makes a mark on the wall after reaching as high as possible without lifting the heels off the floor. This value is recorded, and after that the player jumps as high as possible without taking a step, marking the wall with his fingers at the peak of the jump. The difference between standing and jump reach (to the nearest $0.5 \mathrm{~cm}$ ) was recorded.

Medicine ball throwing test was a modified test known as Seated Shot Put Throw (Gillespie \& Keenum, 1987). The procedure was the same, except medicine ball (2 $\mathrm{kg}$ ) was used instead of shot put.

To test basketball skills the following tests were also applied: speed spot shooting, passing, control dribble and defensive movement. These tests are standardized, with good metric characteristics and they were proposed by the
American Alliance for Health, Physical Education, Recreation and Dance (AAHPERD, 1984).

Statistical analysis. The following elementary descriptive parameters were calculated: means, standard deviations, maximum and minimum. ANOVA (Post Hoc Test) was used to compare the three groups of participants. The level of significance was set at $(\mathrm{p}<0.05)$.

\section{RESULTS}

As we can see in Table I, in average body height participants scored 95 percentile when compared with American population (Malina et al., 2004a). In body mass, participants were in 90 percentile and they were in 50 percentile of BMI when compared with American population (Malina et al., 2004a). Results in basketball skills tests can be compared with those of AAHPERD. The subjects performed better in tests of control of both dribbling and passing. However, their performance was poorer in the other two tests.

Based on the values of $\mathrm{F}$ and $\mathrm{p}$ significance, Table II shows statistically significant differences between groups were obtained in the following variables: Body height, Body mass, BMI, Control dribble, Defensive movement, Medicine ball throwing, Agility run 4x15 and The line drill ( $\mathrm{p}<0.01$ ), and also in variables: Speed spot shooting, Passing, Run 20, 30 and $50 \mathrm{~m}$, Agility T-test and Zigzag agility ( $\mathrm{p}<0.05)$. A significant difference did not appear only in the variable Vertical jump.

Table I. Means, standard deviations, maximum and minimum values of body height, body mass, BMI, mature offset, EAPHV and athletic skills variables of all participants.

\begin{tabular}{lrrr}
\hline Variables & \multicolumn{1}{c}{ Mean \pm SD } & \multicolumn{1}{c}{ Max. } & \multicolumn{1}{c}{ Min. } \\
\hline Body height (cm) & $185.40 \pm 10.6$ & 205.00 & 160.00 \\
Body mass (kg) & $68.12 \pm 11.70$ & 93.00 & 44.00 \\
BMI $\left(\mathrm{kg} / \mathrm{m}^{2}\right)$ & $19.67 \pm 1.85$ & 24.10 & 16.42 \\
Mature offset & $0.17 \pm 0.68$ & 1.63 & -1.46 \\
EAPHV & $13.94 \pm 0.68$ & 15.22 & 12.52 \\
Speed spot shoot (point) & $29.12 \pm 5.74$ & 40.00 & 20.00 \\
Passing (point) & $96.96 \pm 12.33$ & 127.00 & 69.00 \\
Control dribble (s) & $16.00 \pm 1.16$ & 19.26 & 13.47 \\
Defensive movement (s) & $22.12 \pm 1.70$ & 27.11 & 18.63 \\
Vertical jump (cm) & $43.88 \pm 5.45$ & 56.00 & 32.00 \\
Run 20 m (s) & $3.58 \pm 0.24$ & 4.17 & 3.24 \\
Run 30 m (s) & $4.97 \pm 0.45$ & 6.20 & 4.28 \\
Run 50 m (s) & $7.89 \pm 0.38$ & 9.10 & 6.57 \\
Med. ball throw. (m) & $5.43 \pm 0.80$ & 7.10 & 3.75 \\
Agility T-test (s) & $10.98 \pm 0.72$ & 13.37 & 9.50 \\
Zigzag agility drill (s) & $7.16 \pm 0.52$ & 8.37 & 5.93 \\
Agility run 4x15 & $14.72 \pm 0.91$ & 17.42 & 12.93 \\
The line drill (s) & $32.09 \pm 1.99$ & 38.38 & 27.34 \\
\hline
\end{tabular}




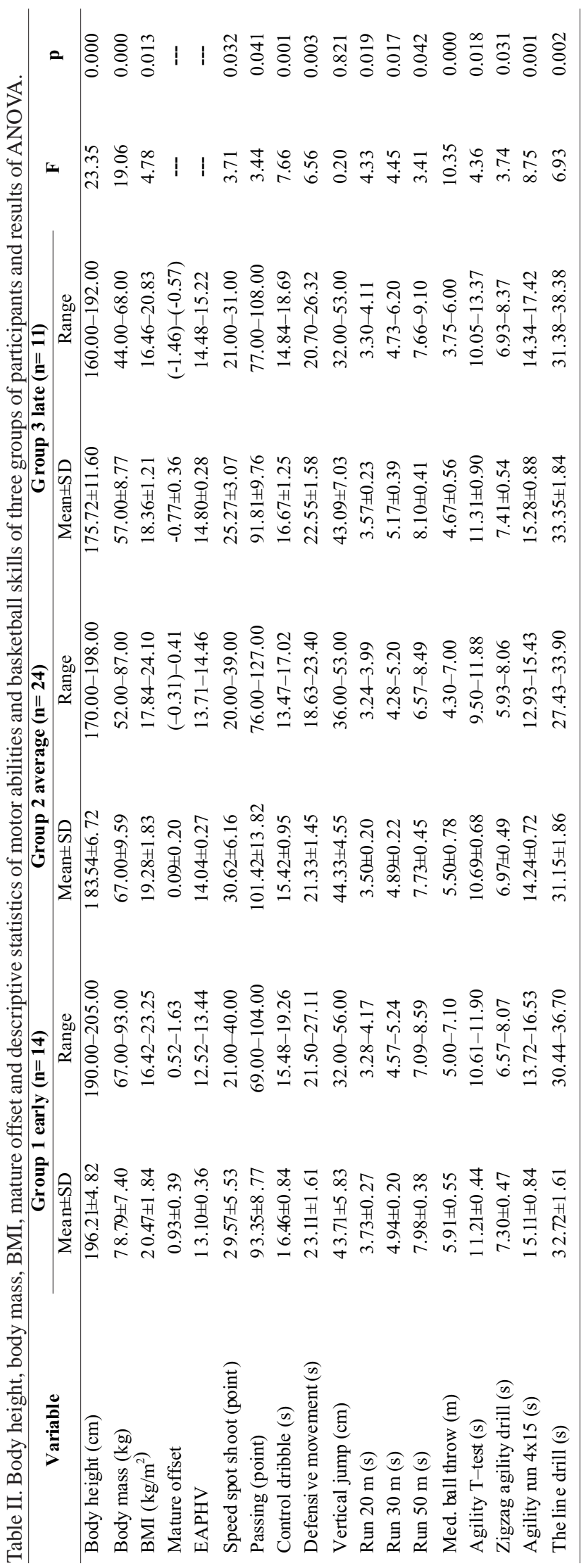

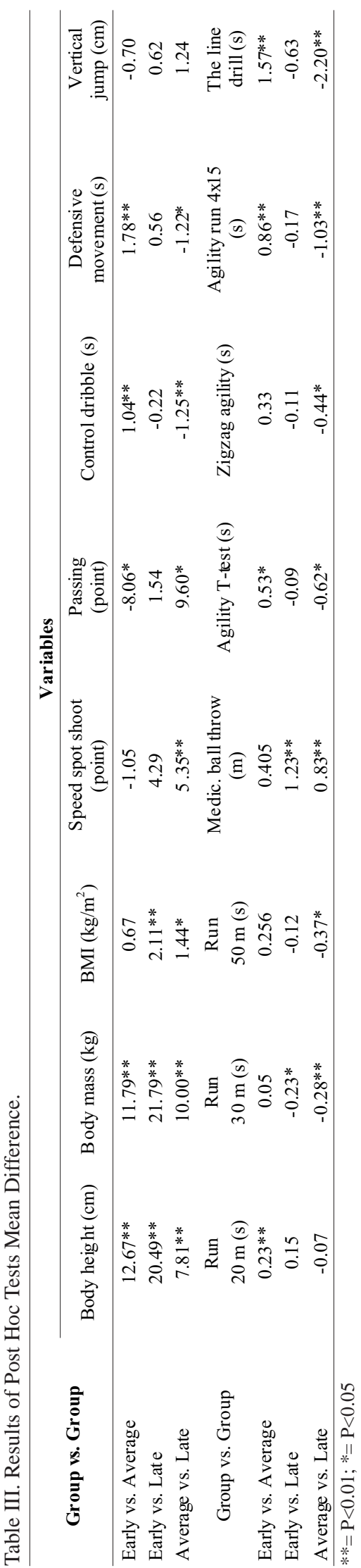

Table III shows that all three groups differed significantly in the body height and body mass, while there was no difference in BMI variables between early and average maturers. Early and average maturers differed significantly in the following variables: Control dribble, Defensive movement, Run 20 m, Agility run $4 \times 15$ and The line drill ( $\mathrm{p}<0.01$ ), and also in variables Passing and Agility T-test ( $\mathrm{p}$ $<0.05)$. Average maturers achieved better results. Early and late maturers differed significantly in only two variables: Medicine ball throwing $(\mathrm{p}<0.01)$ and Run $30 \mathrm{~m}$ (p $<0.05$ ), where early maturing players had the advantage in both tests. Average and late maturers did not differ in only two variables: Vertical jump and 20 $\mathrm{m}$ run, but there were significant differences in the following variables: Speed spot shooting, Control dribble, Run30 m, Medicine ball throwing, Agility run $4 \times 15$ and The line drill ( $\mathrm{p}<0.01$ ), as well as in: Passing, Defensive movement, Run $50 \mathrm{~m}$, Agility T-test and Zigzag agility ( $\mathrm{p}<0.05$ ). Average maturers achieved better results in all mentioned tests. 


\section{DISCUSSION}

Based on their physical characteristics (Tables I and II), it could be said that the subjects in this research were a more satisfactory sample when compared with the subjects used in similar researches, i.e. with the standards of general population of this age (Malina et al., 2004a). Results in tests of basketball skills were on the same level as standards or the results of the American population of young basketball players (AAHPERD). Since there are not many data for this age, these results can be included in the data base for comparison of young talented basketball players.

Results shown in Tables II and III obviously indicate that grouping children into categories according to their chronological age could be wrong. By doing that, children with currently better mostly anthropometric characteristics (body height, most of all) could be favored. These characteristics could be significantly different due to considerable differences in biological age. Children, who are currently biologically less mature, have a longer interval for biological maturation, as well as for reaching and even surpassing those who are currently taller, i.e. those who reached PHV in height earlier.

Biological maturity is conditioned by the PHV in body height and mass, so this difference was expected (Malina $e t$ al., 2004a; Haibach et al., 2011) (Table III). BMI as an indirect indicator of nutrition and body composition in all three groups was expectedly in favor of athletic built, regardless of the boys' biological ages. Athletic built is caused by training process and directed towards development of muscle mass together with increased fat consumption in order to increase the level of energy (Malina et al., 2000; Guyton \& Hall, 2006).

In sports selection of basketball players, longitudinal morphological dimensions which also reflect one's age are considered. However, regardless of the dominance of these characteristics, in motor abilities (especially those which are genetically predisposed (jump, running $20 \mathrm{~m}$, i.e. explosiveness, speed) and those which reflect learned and adopted coordinative patterns and techniques), best results were achieved by the subjects from the average group, and not by early maturers, although the latter would be expected based on their anthropometric characteristics. Obviously, harmonized biological and chronological growth and development contribute to achieving the best results in performance of motor abilities based on morphological characteristics.

Advantage that average group had when compared to early maturers in most motor tests (agility) could be explained through abrupt growth and other longitudinal dimensionalities in the early group, when their central nervous systems were not yet prepared for achieving coordination between biomechanical chain of longitudinal dimensionalities when fulfilling the tasks which were learned and adopted earlier (Haibach et al.). Early maturers were biologically more mature, taller and we suppose with higher body mass, i.e. muscle mass, in absolute values, considering the fact that the development of muscle mass follows the curve of the increase of body mass (Haibach et al.), and they did better in motor tests in which strength is shown (medicine ball throwing).

Average maturers did better in almost all tests when compared with late maturers, except in those which mainly reflected natural, genetically determined characteristics explosiveness and speed (jumping and speed at $20 \mathrm{~m}$ running). Those characteristics, together with longitudinal dimensionality, are among the most important in sports selection process, based on which the boys have entered the high-specific training regime, i.e. this highly selected sample of subjects. Successfulness in other tests was conditioned by higher biological age which led to greater height, body mass, muscle and bone mass (in their absolute values) (Haibach $e t$ al.).

However, this study also has some limitations. Firstly, boys aged 14 have reached the period of the beginning of acceleration as well as significant differentiation of their abilities in relation to their genetic predispositions and the factor of training. Secondly, the subjects in this study were highly selected on the principle of the degree of talent, i.e. their potential, not their current abilities. The period and quality of training, which was conducted in various clubs and according to various training procedures, were not considered, although these factors could have had a significant influence on boys' motor abilities. Thirdly, it would be interesting to conduct a research on the population of boys who were not highly selected in order to establish to which degree early, average and late maturing occurred, and the differences which occurred among them concerning all characteristics we researched in this paper.

Despite the limitations above we believe that findings of this study can help to the coaches to make better training and selection process.

\section{CONCLUSION}

This paper shows that, although it is one of the most important factors on the basis of which young basketball players are recruited and selected, body height is not the 
factor which predominantly determines best motor abilities as well. We believe that only harmonized chronological and biological age, i.e. chronological and biological growth and development, enable the best demonstration of motor abilities based on morphological characteristics. On the other hand, if morphological and motor development and maturity are not harmonized, this can lead to certain unwanted consequences, such as stagnation in motor abilities and injuries. This can further hinder athlete's achieving top results, as well as his further active participation in basketball/sports. These are the reasons why transferring biologically more mature young basketball players /athletes to chronologically older categories should be done with extreme caution. This is especially important when working with older selections of athletes, where the question put to their coaches and sports doctors is whether young athletes of higher biological age should be included in trainings and competitions for seniors, if they are still chronologically juniors. We believe that these findings should be carefully considered by coaches, so as to avoid making their selections based on prejudices.

JAKOVLJEVIC，S.; MACURA，M.; RADIVOJ, M.; JANKOVIC, N.; PAJIC, Z. \& ERCULJ, F. Estado de madurez biológica y desempeño motriz en jugadores de baloncesto de catorce años de edad. Int. J. Morphol., 34(2):637-643, 2016.

RESUMEN: Los objetivos fueron detectar la madurez biológica y ciertas habilidades atléticas en los varones mayores de 14 años que participan en el baloncesto competitivo, y compararlas en función de su estado de madurez biológica. La muestra se conformó con jugadores de baloncesto serbios de mayor talento $(n=$ 49) que fueron divididos en tres grupos de acuerdo a su estado de madurez: temprana $(n=14)$, promedio $(n=24)$ y tardía $(n=11)$. El estado de madurez biológica de los participantes se evaluó mediante la técnica desarrollada por Mirwald et al. (2002). Se aplicaron nueve pruebas de habilidades atléticas básicas: salto vertical, lanzamiento de balón medicinal, carrera de 20, 30 y 50 m, prueba t de agilidad, agilidad en zig-zag, carrera en 4x15 m, línea de perforación, así como pruebas de campo de baloncesto de cuatro habilidades (velocidad de disparos punto, de paso, control de regate y movimiento defensivo). Los resultados de este estudio mostraron que los tres grupos de sujetos diferían en variables aplicadas ( $\mathrm{p}$ $<0,05)$. Los jugadores de maduración media obtuvieron los mejores resultados en casi todas las variables, mientras que los jugadores de maduración tardía alcanzaron los peores resultados. Los jugadores de maduración temprana lograron el mejor resultado en sólo una variable - el lanzamiento de balón medicinal. Solamente el desarrollo cronológico armónico y la edad biológica, es decir, el crecimiento y el desarrollo cronológico y biológico, permiten la mejor demostración de las habilidades motoras basadas en características morfológicas.

PALABRAS CLAVE: Edad cronológica; Edad biológica; Destrezas motrices; Aptitudes en baloncesto.

\section{REFERENCES}

American Alliance for Health, Physical Education, Recreation and Dance (AAHPERD). Basketball for Boys and Girls: Skill Test Manual. Reston, American Alliance for Health, Physical Education, Recreation and Dance, 1984.

Beunen, G. P.; Malina, R. M.; Renson, R.; Simons, J.; Ostyn, M. \& Lefevre, J. Physical activity and growth, maturation and performance: a longitudinal study. Med. Sci. Sports Exerc., 24(5):576-85, 1992.

Bloomfield, J.; Ackland, T. R. \& Elliot, B. C. Applied Anatomy and Biomechanics in Sport. Melbourne, Blackwell Scientific Publications, 1994.

Buchanan, P. A. \& Vardaxis, V. G. Sex-related and age-related differences in knee strength of basketball players ages 11-17 years. J. Athl. Train., 38(3):231-7, 2003.

Coehlo E Silva, M. J.; Figueiredo, A. J.; Moreira Carvalho, H. \& Malina, R. M. Functional capacities and sport-specific skills of 14- to 15-year-old male basketball players: Size and maturity effects. Eur. J. Sport Sci., 8(5):277-85, 2008.

Delorme, N. \& Raspaud, M. The relative age effect in young French basketball players: a study on the whole population. Scand. J. Med. Sci. Sports, 19(2):235-42, 2009.

Gillespie, J. \& Keenum, S. A validity and reliability analysis of the seated shot put as a test of power. J. Hum. Mov. Stud., 13:97105, 1987.

Guyton, A. C., \& Hall, J. E. Textbook of Medical Physiology. 11 $1^{\text {th }}$ ed. Philadelphia, Elsevier Saunders, 2006.

Haibach, P.; Reid, G., \& Collier, D. Motor Learning and Development. Champaign (Il), Human Kinetics, 2011.

Iuliano-Burns, S.; Mirwald, R. L. \& Bailey, D. A. Timing and magnitude of peak height velocity and peak tissue velocities for early, average, and late maturing boys and girls. Am. J. Hum. Biol., 13(1):1-8, 2001.

Kurelic, N.; Momirovic, K.; Stojanovic, M.; Sturm, J.; Radoevic, D. J. \& Viskic-Stalec, N. Structure and development of morphologic and motor dimensions in youth. In Serbian. Beograd, Institut za naucna istrazivanja Fakulteta za fizicko vaspitanje Univerziteta u Beogradu, 1975.

Macura, M.; Jerkovic, B.; Dordevic-Nikic, M.; Milanovic, I. \& Dabovic, M. The differences of the applied methods in the assessment of body composition of adolescent boys. Phys. Cult., 64(2):5-13, 2010.

Malina, R. M. Physical activity and training: effects on stature and the adolescent growth spurt. Med. Sci. Sports Exerc., 26(6):75966, 1994. 
Malina, R. M.; Peña Reyes, M. E.; Eisenmann, J. C.; Horta, L.; Rodrigues, J. \& Miller, R. Height, mass and skeletal maturity of elite Portuguese soccer players aged 11-16 years. J. Sports Sci., 18(9):685-93, 2000.

Malina, M. R.; Eisenmann, J. C.; Cumming, S. P.; Ribeiro, B. \& Aroso, J. Maturity-associated variation in the growth and functional capacities of youth football (soccer) players 13-15 years. Eur. J. Appl. Physiol., 91(5-6):555-62, 2004a.

Malina, R.; Bouchard, C. \& Bar-Or, O. Growth, Maturation and Physical Activity. Champaign (Il), Human Kinetics, 2004b.

Mirwald, R. L.; Baxter-Jones, A. D.; Bailey, D. A. \& Beunen, G. P. An assessment of maturity from anthropometric measurements. Med. Sci. Sports Exerc., 34(4):689-94, 2002.

Moir, G.; Button, C.; Glaister, M. \& Stone, M. H. Influence of familiarization on the reliability of vertical jump and acceleration sprinting performance in physically active men. J. Strength Cond. Res., 18(2):276-80, 2004.

Pauole, K.; Madole, K.; Garhammer, J.; Lacourse, M. \& Rozenek, R. Reliability and validity of the T-test as a measure of agility, leg power, and leg speed in college-aged men and women. $J$. Strength Cond. Res., 14(4):443-50, 2000.

Seminick, D. Tests and measurements: The T-test. Natl. Strength Cond. Assoc. J., 12(1):36-7, 1990a.

Seminick, D. Tests and measurements: The line drill test. Natl. Strength Cond. Assoc. J., 12(2):47-9, 1990b.

Sherar, L. B.; Baxter-Jones, A. D.; Faulkner, R. A. \& Russell, K. W. Do physical maturity and birth date predict talent in male youth ice hockey players? J. Sports Sci., 25(8):879-86, 2007.

Sinobad, M. Poreenje antropometrijskih karakteristika i telesnog sastava izmeu skolske dece i kosarkasa istog uzrasta. Sport. Med., 5(2):43-53, 2005.

Torres-Unda, J.; Zarrazquin, I.; Gil, J.; Ruiz, F.; Irazusta, A.; Kortajarena, M.; Seco, J. \& Irazusta, J. Anthropometric, physiological and maturational characteristics in selected elite and non-elite male adolescent basketball players. J. Sports Sci., 31(2):196-203, 2013.

Wickel, E. E. \& Eisenmann, J. C. Maturity-related differences in physical activity among 13- to 14-year-old adolescents. Pediatr. Exerc. Sci., 19(4):384-92, 2007.
Correspondence to:

Prof. Sasa Jakovljevic, PhD

University of Belgrade

Faculty of Sport and Physical Education

Blagoja Parovica 156

11000 Belgrade

SERBIA

Tel: +381603200935

Fax: +3813531100

Email: sasa.jakovljevic@fsfv.bg.ac.rs

Received: 07-12-2015

Accepted: 30-03-2016 